\title{
The first record of Rbapbigaster nebulosa (Poda, 1761) (Heteroptera: Pentatomidae) for Voronezh Region and notes about the host- parasitic relationships with Cylindromyia bicolor (Olivier, 1812) (Diptera: Tachinidae)
}

\author{
Первое указание Rbaphigaster nebulosa (Poda, 1761) (Heteroptera: \\ Pentatomidae) из Воронежкской области и заметки о хозяинно- \\ паразитических связях с Cylindromyia bicolor (Olivier, 1812) \\ (Diptera: Tachinidae)
}

\author{
E.V. Alksenenko', A.M. Kondratyeva ${ }^{2}$, D.L. Musolin ${ }^{3}$ \\ Е.В. Аксёненко ${ }^{1}$, А.М. Кондратьева ${ }^{2}$, А.А. Мусолин ${ }^{3}$
}

\footnotetext{
${ }^{1}$ Voronezh State University, Universitetskaya Pl. 1, Voronezh 394018, Russia. E-mail: entoma@mail.ru.

${ }^{2}$ All-Russian Research Institute of Forest Genetics, Breeding and Biotechnology, Lomonosov Str. 105, Voronezh 394087, Russia. E-mail: kondratyeva_anya@mail.ru.

${ }^{3}$ Saint Petersburg State Forest Technical University, Institutskiy per. 5, St. Petersburg 194021, Russia. E-mail: musolin@gmail.com.

${ }^{1}$ Воронежский государственный университет, Университетская пл., д. 1, Воронеж 394018, Россия.

${ }^{2}$ Всероссийский научно-исследовательский институт лесной генетики, селекции и биотехнологии, ул. Ломоносова, д. 105, Воронеж 394087, Россия.

${ }^{3}$ Санкт-Петербургский государственный лесотехнический университет имени С.М. Кирова, Институтский пер., д. 5. СанктПетербург 194021, Россия.
}

KEY WORDS. Heteroptera, Pentatomidae, Rhaphigaster nebulosa, Diptera, Tachinidae, Cylindromyia bicolor, fauna, range, climate change, Voronezh Region, Russia.

КЛЮЧЕВЫЕ СЛОВА. Heteroptera, Pentatomidae, Rhaphigaster nebulosa, Diptera, Tachinidae, Cylindromyia bicolor, фауна, ареал, климат, Воронежская область, Россия.

ABSTRACT. The first record of Rhaphigaster nebulosa (Poda, 1761) for Voronezh Region (Russia) is presented. Additionally, information on new findings of Cylindromyia bicolor (Olivier, 1812), which has been known from individual specimens and only from the extreme south of Voronezh Region is provided. The simultaneous records of these two species that are linked by host-parasitic relationships might indicate the expansion of the species' ranges conditioned by the current climate change.

РЕЗЮМЕ. В статье приводится первое указание щитника Rhaphigaster nebulosa (Poda, 1761) из Воронежской области. Также даются сведения о новых находках тахины Cylindromyia bicolor (Olivier, 1812), которая ранее была известна только по единичным экземплярам и лишь с крайнего юга Воронежской области. Одновременное обнаружение двух этих видов, связанных хозяинно-паразитическими отношениями, может свидетельствовать о расши- рении их ареалов в связи с наблюдаемым изменением климата.

\section{Introduction}

Rhaphigaster nebulosa (Poda, 1761) is widespread in Central, Southern and Southeastern Europe, the Caucasus and Transcaucasia, South and Southwestern Kazakhstan, Turkey, Iran, Pakistan, Southeast and Central Asia, and North Africa [Putchkov, 1961; Catalogue of the Heteroptera..., 1999; Neimorovets, 2010]. It has been reported that this pentatomid had been expanding its native range northward during the last two decades [Aukema, Hermes, 2009; Bantock et al., 2011; Ostrovsky, 2017; Pełka et al., 2019].

Rhaphigaster nebulosa has not been recorded previously in Voronezh Region, however, it has been suggested that the northern border of the species distribution should obviously pass through the territory of the region [Putchkov, 1961].

How to cite this article: Aksenenko E.V., Kondratyeva A.M., Musolin D.L. 2021. The first record of Rhaphigaster nebulosa (Poda, 1761) (Heteroptera: Pentatomidae) for Voronezh Region and notes about the hostparasitic relationships with Cylindromyia bicolor (Olivier, 1812) (Diptera: Tachinidae) // Russian Entomol. J. Vol.30. No.2. P.143-145. doi: 10.15298/rusentj.30.2.05 


\section{Materials and methods}

The specimens that were used in this study were collected in Voronezh City in 2010-2020 and deposited in the Arthropod Collection of the Department of Zoology and Parasitology of the Voronezh State University. The specimens of Rh. nebulosa and Cylindromyia bicolor (Olivier, 1812) were obtained during routine local fauna screenings in Voronezh. In total, 73 specimens of $R h$. nebulosa and 5 specimens of $C$. bicolor were collected and examined. Pentatomids were collected manually from soil surface and walls outside and inside buildings. Tachinid flies were collected manually from soil surface and inside buildings. Larvae of the flies that left the collected pentatomids were reared until adult emergence under laboratory conditions. The true bug species were identified based on the classic keys by Kerzhner and Yachevsky [1964] and Putchkov [1961]. Tachinid flies were identified using the keys by Zimin et al. [1970], Tschorsnig and Herting [1994], and Cerretti [2010]. The verification of the tachinid's identification was carried out by the first author using the Diptera Collection of the Zoological Institute of the Russian Academy of Sciences (Saint Petersburg). The major part of the material is preserved in the private collections of the authors and a part was submitted to the Arthropod Collection of the Department of Zoology and Parasitology of the Voronezh State University.

\section{Rhaphigaster nebulosa (Poda, 1761)}

MATERIAL. Russia: Voronezh Region, Voronezh, 1.XI.2010 1 spec., 10.X.2013 - 1 spec., 3.XI.2013 - 1 spec., 27.XI.2013 - 1 spec., 5.III.2014 - 1 spec., 26.III.2014 - 1 spec., 27.III.2014 - 1 spec., 19.IV.2014 - 1 spec., 28.IV.2014 - 1 spec., 17.V.2014 - 1 spec., 23.V.2014 - 1 spec., 6.VI.2014 - 1 spec., 10.VI.2014 - 1 spec., 15.VIII.2014 - 3 spec., 8.IX.2014 - 2 spec., 10.IX.2014 - 3 spec., 1.X.2014 - 1 spec., 8.X.2014 - 1 spec., 10.X.2014 - 1 spec., 20.XI.2014 - 2 spec., 2.XII.2014 - 1 spec., 9.XII.2014 - 1 spec., 10.III.2015 - 1 spec., 11.III.2015 - 2 spec., 14.III.2015 - 1 spec., 17.III.2015 - 3 spec., 19.III.2015 - 2 spec., 20.III.2015 - 1 spec., 24.III.2015 - 2 spec., 27.III.2015 - 2 spec., 8.IV.2015 - 1 spec., 10.IV.2015 - 2 spec., 13.IV.2015 - 1 spec., 27.IV.2015 - 1 spec., 20.V.2015 - 3 spec., 29.V.2015 - 1 spec., 3.VI.2015 - 1 spec., 10.VI.2015 - 1 spec., 10.VIII.2015 - 1 spec., 13.VIII.2015 2 spec., 23.IX.2015 - 2 spec., 14.X.2015 - 2 spec., 20.X.2015 3 spec., 5.XI.2015 - 1 spec., 20.XII.2015 - 2 spec., 20.II.2016-1 spec., 9.III.2016 - 1 spec., 3.X.2016 - 1 spec., 6.V.2017 - 2 spec. (pentatomids were infested by tachinid flies), 12.III.2020 - 1 spec., 15.IV. 2020 - 1 spec.

REMARKS. Dendrobiont. This pentatomid feeds and lives on willows (Salix sp.), poplars (Populus sp.), and hazel (Corylus sp.). It is usually recorded on fruit trees and bushes in Ukraine [Putchkov, 1961]. However, a number of authors draw attention to possible errors in the establishment of trophic links, since some of the recorded plants might be only random plants used by adults to rest just before leaving for overwintering microhabitats [e.g., Bantock et al., 2011]. Univoltine, overwinters at the adult stage.

\section{Cylindromyia bicolor (Olivier, 1812)}

MATERIAL. Russia: Voronezh Region, Voronezh, 13.IX.2015 - 1 spec., 7.V.2017 - 1 spec. (the larva left the host [Rh. nebulosa]; the adult fly emerged from puparium on 26.V.2017), 7.V.2017 - $1 \mathrm{spec}$ (the larva left the host [Rh. nebulosa]; the adult fly emerged from puparium on 27.V.2017), 27.VI.2017 - 1 spec., 4.IX.2019-1 spec.
REMARKS. Subboreal-subtropical, western pancontinental species. Currently, only $R h$. nebulosa is known as a host of this tachinid fly [Tschorsnig, 2017].

\section{Results and discussion}

Even though it was suggested that Rh. nebulosa is likely to be distributed in Voronezh and Kursk Regions [Putchkov, 1961], thorough work of renowned heteropterologists (V.V. Korinek, V.G. Putchkov, V.B. Golub, I.S. Drapolyuk, etc.) in the region resulted in no records of this species [Korinek, 1940; Putchkov, 1964; Golub, Drapolyuk, 2005]. Furthermore, its obligate parasitoid $C$. bicolor has been recoded only once, recently, and in the extreme south of Voronezh Region [Khitsova, 2005]. Thus, it is obvious that in this case we are dealing with an arrival to the region of two ecologically closely related species and we consider it as a gradual expansion of the species' ranges northward. Now, both the pentatomid and its tachinid parasitoid have been found on the territory of Voronezh City. Cylindromyia bicolor was previously observed only in Rostov Region and on its border [Khitsova, 2005, 2019]. Thus, the border of this tachinid has moved more than $200 \mathrm{~km}$ northward.

Both these species have not yet been found outside the city in the neighboring districts of Voronezh Region. It can be assumed that their entry to the territory of Voronezh was associated with an accidental introduction of $R h$. nebulosa, likely from the neighboring regions with some pentatomids infested by eggs of C. bicolor. Both species are thermophilic. Their arrival at the Voronezh Region likely reflects common tendency of thermophilic heteropterans to expand their ranges northward in response to the current climate change [Musolin, 2007; Rabitsch, 2008; Musolin, Saulich, 2012]. Moreover, it is well known that air temperature is higher in large cities than in the surrounding natural landscapes (the so-called heat island phenomena) making the overwintering conditions milder locally and true bugs can utilize these advantages of the urban environments [Tougou et al., 2009].

Further observations are needed to monitor range expansion of these two insect species.

Acknowledgement. We are thankful to Dr. Olga G. Ovchinnikova and Ms. Galina M. Suleymanova for the permission to examine tachinid flies from the Diptera Collection of the Zoological Institute of the Russian Academy of Sciences (Saint Petersburg). We are also grateful to Prof. Viktor B. Golub (Voronezh) for the support provided during the research and his interest in the subject.

The work of E.V.A. and A.M.K. (data collection and preparation) was funded by the Russian Foundation for Basic Research (project number 18-04-00464-a) and work of D.L.M. (data analysis) was funded by the Russian Science Foundation (project number 21-16-00050).

Competing interests. The authors declare no competing interests. 


\section{References}

Aukema B., Hermes D. 2009. [New and interesting Dutch bugs III (Hemiptera: Heteroptera)] // Nederlandse Faunistische Mededelingen. Vol.31. P.53-88 [in Dutch].

Bantock T.M., Notton D., Barclay M.V.L. 2011. Rhaphigaster nebulosa (Pentatomidae: Pentatomini) arrives in Britain // Het News. Iss.17-18. P.5.

Catalogue of the Heteroptera of the Palaearctic Region (B. Aukema, Chr. Rigier, eds.). 1999. Vol.5. Pentatomomorpha II. Amsterdam: The Netherlands Entomological Society. 577 p.

Cerretti, P. 2010. [The tachinids of the Italian fauna (Diptera Tachinidae) with an interactive key of the West-Palearctic generes] // Centro Nationale Biodiversità Forestale, Verona. Cierre Edizioni, Verona. Vol.1. P.1-573 [in Italian]

Golub V.B., Drapolyuk I.S. 2005. [Order Heteroptera] // Kadastr bespozvonochnykh Voronezhskoi oblasti. Voronezh: Voronezh State University. P.276-316 [in Russian].

Kerzhner I.M., Jaczewskii T.L. 1964. [Order Hemiptera (Heteroptera) - bugs] // Opredelitel' nasekomykh evropeiskoi chasti SSSR. M.-L.: Nauka. Vol.1. P.655-845 [in Russian].

Khitsova L.N. 2005. [Family Tachinidae] // Kadastr bespozvonochnykh Voronezhskoi oblasti. Voronezh: Voronezh State University. P.517-531 [in Russian].

Khitsova L.N. 2019. [Tachinid flies (Diptera, Tachinidae) of East European (Great Russian) Plain (ecological and faunistic survey)]. Voronezh: Nauchnaya kniga. 382 p. [In Russian, with English summary]

Korinek V.V. 1940. [Fauna of hemiptran insects (Hemiptera Heteroptera) of the Khoper State Reserve] // Trudy Khoperskogo Zapovednika. Moscow. Vol.1. P.174-218 [in Russian].

Musolin D.L. 2007. Insects in a warmer world: ecological, physiological and life-history responses of true bugs (Heteroptera) to climate change// Global Change Biology. Vol.13. No.8. P.15651585.

Musolin D.L., Saulich A.Kh. 2012. Responses of insects to the current climate changes: from physiology and behavior to range shifts // Entomological Review. Vol.92. No.7. P.715-740.
Neimorovets V.V. 2010. [True Bugs (Heteroptera) of the Krasnodar Territory and the Republic of Adygea. Checklist] // Plant Protection News. Supplement. St. Petersburg - Pushkin: VIZR RAAS. 103 p. [in Russian].

Ostrovsky A.M. 2017. [The first records of Rhaphigaster nebulosa (Poda, 1761) (Hemiptera: Heteroptera: Pentatomidae) in the city of Gomel (Republic of Belarus)] // Eversmannia. No.49. P.52. [in Russian, with English summary].

Pełka A., Markowicz M., Chróścik M. 2019. [First records of Rhaphigaster nebulosa (Poda, 1761) (Hemiptera: Heteroptera: Pentatomidae) in the Eastern Beskid Mts. and the Sandomierz Plain] // Heteroptera Poloniae - Acta Faunistica. Vol.13. P.97100 [in Polish, with English summary].

Putchkov V.G. 1961. [Shieldbugs] // Fauna Ukraïni. Kiïv: Vidavnicztvo Akademiï nauk Ukraiïns'koï RSR. Vol.21. No.1. 338 p. [In Ukrainian].

Putchkov V.G. 1964. [To the fauna and ecology of Heteroptera of Khoper State Reserve and Ramon surroundings] // Ekologiya ta geografichne poshirennya chlenistonogih. Kiïv: Naukova dumka. P.169-179 [in Ukrainian].

Rabitsch W. 2008. Alien true bugs of Europe (Insecta: Hemiptera: Heteroptera) // Zootaxa. Vol.1827. P.1-44.

Tougou D., Musolin D.L., Fujisaki K. 2009. Some like it hot! Rapid climate change promotes changes in distribution ranges of Nezara viridula and Nezara antennata in Japan // Entomologia Experimentalis et Applicata. Vol.130. No.3. P.249-258.

Tschorsnig H.-P. 2017. Preliminary host catalogue of Palaearctic Tachinidae (Diptera) // Version 1.0. PDF document, $480 \mathrm{pp}$. (http://www.nadsdiptera.org/Tach/WorldTachs/CatPalHosts/ Cat_Pal_tach_hosts_Ver1.pdf. Accessed on 15 July 2020).

Tschorsnig H.-P., Herting B. 1994. [The Tachinids (Diptera: Tachinidae) of Central Europe: identification keys for the species and data on distribution and ecology] // Stuttgarter Beitrage zur Naturkunde. Serie A (Biologie). No.506. P.1-170 [in German, with English summary].

Zimin L.S., Zinov'eva K.B., Shtakelberg A.A. 1970. [Family Tachinidae (Larvaevoridae) - tachinid flies] // Opredelitel' nasekomykh Evropeiskoi Chasti SSSR. Dvukrylye, Blokhi. Vol.2. L.: Nauka. P.678-798 [in Russian]. 